Canadian

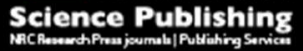

Botany

Botanique

\title{
Revisiting the histological patterns of storage tissues: beyond the limits of gall-inducing taxa
}

\begin{tabular}{|r|l|}
\hline Journal: & Botany \\
\hline Manuscript ID & cjb-2016-0189.R1 \\
\hline Manuscript Type: & Article \\
\hline Date Submitted by the Author: & 02-Sep-2016 \\
\hline Complete List of Authors: & $\begin{array}{l}\text { Ferreira, Bruno; Universidade Federal de Minas Gerais, Botânica } \\
\text { Álvarez, Rafael ; Universidad de Leon, } \\
\text { Avritzer, Sofia; Universidade Federal de Minas Gerais, Botânica } \\
\text { Isaias, Rosy; Universidade Federal de Minas Gerais, Botânica }\end{array}$ \\
\hline Keyword: & Aphid galls, Eriophyid galls, Nematode galls, Nutritive tissue, Storage cell \\
\hline & \multicolumn{2}{|l}{} \\
\hline
\end{tabular}


Revisiting the histological patterns of storage tissues: beyond the limits of gall-inducing taxa

Bruno G. Ferreira ${ }^{1}$, Rafael Álvarez ${ }^{2}$, Sofia C. Avritzer ${ }^{1}$, Rosy M. S. Isaias*1

${ }^{1}$ Universidade Federal de Minas Gerais, Instituto de Ciências Biológicas, Dept.

Botânica. Av. Antônio Carlos, 6627, CP 406. Belo Horizonte, Minas Gerais

31270-901, Brazil. bruno.garcia.ferreira@gmail.com; sofiavritzer@gmail.com;

rosy@icb.ufmg.br

${ }^{2}$ Universidad de León, Facultad de Ciencias Biologicas y Ambientales, Dept.

Biología Molecular, Área Biología Celular. León 24071, Spain.

ralvn@unileon.es

* Corresponding author: Rosy M. S. Isaias. Phone: +553134092687. Fax:

+553134092671. E-mail address: rosy@icb.ufmg.br 


\section{Abstract}

Gall-inducing Aphididae may feed directly on phloem, while Eriophyidae and Nematoda feed on cells lining the gall chambers. We assume that a variation in structural complexity will occur within galls induced by each taxon, and that the complexity of the galls could be related with the types of storage tissue they have. Histological, histometric and histochemical analyses were used to compare six gall systems, which have different levels of complexity. Such levels are not taxon-related, even though eriophyid galls are usually simpler than nematode and aphid galls. The histological features of galls allowed the classification of storage tissues in three types: 'typical nutritive tissues' (TNT), 'common storage tissues' (CST), and 'nutritive-like tissues' (NLT). The TNT and NLT have cells with dense cytoplasm and a prominent nucleus. The CST cells are vacuolated, and may store starch and other energy-rich molecules, as do the NLT cells. In contrast to NLT or CST, the TNT serves as direct food source for gall inducers, and it is present in nematode and some eriophyid galls. NLTs may be present in some aphid galls, but are not the direct feeding site. The CST occurs on galls of all three inducing taxa.

Key words: Aphid galls; Eriophyid galls; Histology; Nematode galls; Nutritive tissue; Storage cell 


\section{Introduction}

Galls are products of an intrinsic relationship between specific parasites and their host plants (Mani 1964), where the gall inducers govern plant developmental processes such as cell hypertrophy and redifferentiation, hyperplasia, and/or alteration of meristematic activity (Mani 1964; Bronner 1992; Álvarez et al. 2009, 2013; Oliveira and Isaias 2010; Ferreira and Isaias 2013; Fleury et al. 2015). The alterations in plant histogenesis are linked to the sink strength in galls (Larson and Whitham 1991; Inbar et al. 1995; Castro et al. 2012; Fleury et al. 2015), and provide essential energy-rich molecules for gall growth and maintenance, and for the inducer's nutrition. Even though the galling habit evolved independently in non-related groups of Animalia (Acari, Nematoda, and Insecta) (Meyer 1987), the galls show convergent structural arrangements related to the similar feeding habits of the inducers (Larew 1981; Bronner 1992; Rohfritsch 1992; Oliveira and Isaias 2010; Oliveira et al. 2011; Ferreira and Isaias 2013). In addition to providing nutrition, gall structure may offer protection against natural enemies, such as parasitoids, pathogens and inquilines, as well as an adequate microenvironment for the development of the offspring (Price et al. 1987; Stone and Schonrogge 2003). Moreover, some conservative features such as storage, cell and trichome types, secretory structures, arrangement of vascular bundles, and some cytological features may represent constraints imposed by the host plant, and consequently determine gall histology (Moura et al. 2009; Oliveira et al. 2010; Ferreira and Isaias 2014).

Galls induced by insects can be histologically divided into two groups: (1) those induced by chewing (Lepidoptera and Hymenoptera) and scraping- 
sucking insects (Diptera: Cecidomyiidae); and (2) those induced by sucking insects (Hemiptera) (Weidner 1961 apud Larew 1981). The galls of chewing and scraping-sucking insects have 'typical nutritive tissues' (TNT) surrounding the gall chamber. The TNT is a storage tissue used as the food source for the inducer. Its cells are usually cytoplasm-rich, with a prominent nucleus and nucleoli (Kostoff and Kendall 1929; Bronner 1992; Ferreira et al. 2015; Oliveira et al. 2011, 2016). TNT cells usually accumulate proteins, lipids or reducing sugars, depending on the gall-inducing species (Bronner 1992; Oliveira and Isaias 2010; Vecchi et al. 2013; Ferreira and Isaias 2013, 2014).

Galls induced by sucking insects are not thought to have nutritive tissues, because their inducers suck directly on vascular bundles (Larew 1981; Bronner 1992). However, storage tissues with cells that accumulate starch, here termed 'common storage tissues' (CST), surround the vascular bundles (Álvarez et al. 2009, 2013; Oliveira and Isaias 2010; Isaias et al. 2011; Muñoz-Viveros et al. 2014). In specific cases, when the cells store starch and reducing sugars and have an active nucleus and dense cytoplasm (Carneiro and Isaias 2014, 2015; Carneiro et al. 2014; Richardson et al. 2016), the CST are termed 'nutritive-like tissues' (NLT) (sensu Richardson et al. 2016). NLT and CST are histologically distinguished by the vacuoles (large in CST; fragmented in NLT), nucleus (nonprominent in CST; prominent in NLT), and cytoplasm (peripheral and inconspicuous in CST; dense in NLT). Sucking gall-inducing animals such as Nematoda and Acari induce colonial galls with TNT (Kendall 1930; Goodey 1939, 1948; Watson and Shorthouse 1979; Skinner et al. 1980; Larew 1981; Westphal et al. 1981; Moura et al. 2008, 2009; Ferreira et al. submitted). The stylets of these inducers are shorter than the stylets of the hemipterans, and 
they are accordingly capable of feeding only on the cells immediately adjacent to the chamber (Dropkin 1969; Westphal et al. 1981).

The different types of storage parenchyma may be present in galls induced by different animal groups, and these types vary cytologically according to the functions of the cells in each galling system. Different authors distinguish storage tissues in galls with an array of terms, such as: 'parenchymatic nutritive tissue' and 'nutritive tissue' (Sliva and Shorthouse 2006), 'nutritive-like parenchyma' (Oliveira and Isaias 2010), 'storage nutritive tissue' and 'typical nutritive tissue' (Ferreira and Isaias 2013; Ferreira et al. 2015), 'true nutritive tissue' not eaten by the inducer (Carneiro and Isaias 2015) and 'nutritive-like tissue' (Richardson et al. 2016). Detailed analyses of these types of tissues revealed some convergent and divergent structural and functional features, which led us to propose a standard classification for these storage tissues. We believe that the use of a standard classification will be an important step for future investigations of cytological, histochemical, and functional patterns in gall storage tissues.

Presuming that the feeding habits of the gall inducers would predict the histological patterns of the galls, colonial galls should have the same histological patterns as solitary galls. We aimed to compare features of galls induced by three groups: aphids, nematodes, and mites, using an array of morphological tools and data from the literature. The level of structural complexity of the gall is as high as the range of developmental alterations they have. We considered the occurrence of hyperplasia, cell hypertrophy, hypertrophy of vascular bundles, cell redifferentiation, histochemical changes, and manipulation of meristematic activity as the wider amplitude of gall 
complexity. Assuming the range of developmental alterations within each gall group, we test if the complexity of the galls is related to the types of storage tissues they have. Finally, we propose to standardize the nomenclature for storage tissues in galls, based on galls induced by three phylogenetically distant groups of gall inducers.

\section{Material and methods}

Collection and histological processing

Non-galled leaves (controls) and galls (Table 1 ) were collected ( $n=5$ for each category), fixed in Karnovsky's solution (Karnovsky 1965) or in FAA (Johansen 1940), dehydrated in a butyl or ethyl series (Kraus and Arduin 1997), embedded in Paraplast $\circledast$, and sectioned using a rotary microtome (12 $\mu \mathrm{m})$. The slides were deparaffinized, stained with $0.5 \%$ astra blue and $0.5 \%$ safranin $(9: 1)$ (Kraus and Arduin 1997), or with 1\% safranin and $1 \%$ fast green (Johansen 1940 ) in order to distinguish cell walls with lignin or suberin, vacuoles with phenolics, and nucleus (red stained) from pectocellulosic cell walls and cytoplasm (blue stained). After staining, the slides were dehydrated and mounted in clear varnish (Paiva et al. 2006) or Entellan®.

Histochemistry

The sections were treated with Lugol's reagent to detect starch (Johansen 1940), Fehling's reagent for reducing sugars (Sass 1951), Ponceau 2R for proteins (Ventrella et al. 2013), or Sudan red B for lipids (Jensen 1962). Histometry 
In order to evaluate the occurrence of hyperplasia and hypertrophy, 3 randomly selected regions of median sections of the galls and controls $(n=5)$ were photographed, and the number of cell layers was counted. The area of 5 cells of each tissue was measured in each section. In aphid galls and their controls, the height (anticlinal diameter) of the xylem and phloem (transverse sections) of secondary veins was measured. In midrib galls induced by Geoica utricularia on Pistacia terebinthus, the tissues of the non-galled midrib were considered as control tissues, and the two rows of vascular bundles (adaxial supernumerary bundles and main central bundles) were measured, separately.

The measurements were compared using the software SigmaStat $®$ by means of a t-test (when raw or transformed data showed a normal distribution and were homoscedastic) or a Mann-Whitney test (when the data, even after transformations, were not normal and/or homoscedastic). In some cases, two kinds of leaf parenchyma were compared with gall parenchyma(s), and the data were compared with one-way analysis of variance (ANOVA) followed by Tukey's post-test (normal and homoscedastic data) or Kruskal-Wallis test followed by Dunn's post-test (non-normal and/or non-homoscedastic data even after transformations). We considered the differences to be statistically significant when $p<0.05$.

\section{Results}

Aphid galls

Eriosoma ulmi. The galls are formed by rolling one leaf margin toward its abaxial surface (Fig. 1A), and have three kinds of tissue regions. The first is similar to the non-galled mesophyll (Fig. 1B); the second is almost unaffected 
but with some tissue homogenization (Fig. 1C); and the third is the folding region, with noticeable hypertrophy of the parenchyma cells and hyperplasia (Fig. 1D). The sites of parenchyma hyperplasia have 2-fold thicker mesophyll than that of the non-galled leaf lamina (Table 2). The phloem faces the gall chamber (Fig. 1D). The epidermal cells on both surfaces and the parenchyma cells are hypertrophied (Table 2). Xylem and phloem areas increase in gall sites compared with the controls (Table 2). Gall parenchymatic cells are highly vacuolated, with thin cytoplasm. Reducing sugars accumulate in the gall vascular bundles and endodermis (Fig. 1E), as well as in the controls. Small amounts of accumulated proteins (Fig. 1F-G) but no starch was detected in the gall tissues (Table 2). No storage tissues differentiate (Table 3).

Geoica utricularia: The galls are globoid (Fig. 2A), induced on the midrib (Fig. 2B) of young leaflets. They are formed by the growth of a pouch on the midrib toward the abaxial surface. Unicellular trichomes close the small aperture. The inner (adaxial) epidermis is multiseriate, with small holes linking the gall chamber and gall parenchyma (Fig. 2C). The gall wall can be divided into inner and outer homogeneous parenchyma (Fig. 2C). The parenchyma shows marked hyperplasia and cell hypertrophy (Table 2). The inner parenchyma layers accumulate proteins, starch, and reducing sugars (Fig. 2D; Table 2), with cytoplasm-rich cells that have prominent nucleus (Fig. 2E; Table 3). The midribs of the control (Fig. 2B) and of the galls (Fig. 2C) have two rows of vascular bundles: the adaxial supernumerary and the abaxial main bundles. The phloem portion of the supernumerary bundles faces the adaxial surface (Fig. 2C, E), and is significantly hypertrophied in galls (Table 2). Both phloem bundles of the galls have secretory ducts (SD) (Fig. 2C, E), whereas the supernumerary 
bundles of the controls lack the secretory duct associated with the phloem (Fig. 2B).

Nematode galls

Ditylenchus gallaeformans on Miconia albicans. The globoid verrucous galls are induced on leaves (Fig. 3A-B), stems and inflorescences of M. albicans (Melastomataceae). Colonies of nematodes are surrounded by gall emergences (Fig. 3C-E). The outer epidermis is not in contact with the colonies, and is densely covered with arachnoid trichomes (Figs. 3C-E). These trichomes are lignified and form a denser layer on the galls than on the controls (Fig. 3C; Table 4). The subjacent outer homogeneous parenchyma develops under the outer epidermis (Fig. 3C-G), and has polyhedral cells and idioblasts with druses (Fig. 3E), better seen under polarized light (Fig. 4A). Discrete collateral vascular bundles are embedded in the outer parenchyma (Fig. 3E-F). The cells in contact with the larvae are meristematic, and originate new emergences that grow to surround the nematode colonies (Fig. 3D-E). The cells of the inner parenchyma and epidermis of the nematode chamber constitute the nutritive tissue (Fig. 3F-G). These cells are smaller than the cells of the non-galled leaf portions (Fig. 3E-F; Table 4), and have a dense granulose cytoplasm, a prominent nucleus, and thin cell walls (Figs. 3F-G). Adventitious leaves may also appear in the lateral regions. Starch grains occur in the outer parenchyma cells (Fig. 4B), while proteins and reducing sugars (Fig. 4C) occur in the nutritive cells (Table 3). Parenchyma hyperplasia is the main process that forms these galls, while cell hypertrophy is not observed (Table 4). The inner (nutritive) cells are smaller than the cells of the non-galled leaves (Table 4). 
Ditylenchus gallaeformans on Miconia ibaguensis. The globoid verrucous galls are induced on leaves of M. ibaguensis (Fig. 5A-B). Emergences surround the colonies of nematodes (Fig. 5B-C). The outer epidermis, not in contact with the nematodes, is densely covered with stellate trichomes (Fig. 5C). An outer parenchyma with polyhedral cells and idioblasts with druses develops under the outer epidermis (Fig. 5B-C). Discrete collateral vascular bundles are embedded in the outer parenchyma (Fig. 5D). The cells in contact with the larvae are meristematic, and originate new emergences that grow to surround the nematode colonies (Fig. 5C-D). The cells of the inner parenchyma and epidermis of the nematode chamber constitute the nutritive tissue (Fig. 5D). These cells are smaller than the cells of the non-galled leaf portions (Table 4), and have a dense granulose cytoplasm, a prominent nucleus, and thin cell walls (Fig. 5D). Adventitious leaves usually appear in the lateral regions (Fig. 5A-B). Starch grains occur in the outer parenchyma cells, while proteins (Fig. 5E) and reducing sugars (Fig. 5F) occur in the nutritive cells (Table 3). Parenchyma hyperplasia is the main process that forms these galls, while cell hypertrophy is not observed (Table 4). The inner (nutritive) cells are smaller than the cells of the non-galled leaves (Table 4).

\section{Eriophyid galls}

Galls of unidentified eriophyid: The galls are formed by a bulging of the leaf lamina of $M$. ibaguensis, usually forming blisters directed toward the adaxial surface (Fig. 6A-B), with a dense indumentum on the abaxial surface (Fig. 6CD), where the mites live and feed. Sometimes a dense indumentum may also develop on the adaxial surface. The galls have homogeneous parenchyma (Fig. 6D-E), with no alterations in the number of cell layers or in the thickness of the 
mesophyll compared to the control leaves (Table 5). Cell hypertrophy does not occur (Table 5). The indumentum is formed by long emergences with one layer of epidermis and 1-3 layers of parenchyma (Fig. 6E-G). The emergences are considerably larger and denser than in the controls (Fig. 6E-D) (Table 5). The mites feed on vacuolated cells of the epidermis located among and on the bases of the emergences (Fig. 6E-F; Table 3). Reducing sugars (Fig. 6H) occur in the epidermis of the chamber (Table 3). Proteins, starch (Fig. 6I), and lipids accumulate equally in galled and non-galled parenchyma (Table 5).

Aceria tristriata: The galls are small and lenticular (Fig. 7A-B). An aperture is usually present on the abaxial surface. In galls, the leaf thickness increases considerably (Fig. 7A) through hyperplasia and cell hypertrophy (Table 5). The epidermis is simple, and the gall mesophyll has homogeneous parenchyma, sometimes with a small bundle embedded in the median region (Fig. 7C). The surface of the nymphal chamber consists of nutritive cells, sometimes disrupted by the eriophyid feeding (Fig. 7D). The nutritive cells have a large prominent nucleus and granulose cytoplasm (Fig. 7D-F), and accumulate a considerable amount of proteins (Fig. 7E) and some oil drops (Table 3). The non-nutritive parenchyma cells are not in contact with the mites, and have large vacuoles and a peripheral cytoplasm (Fig. 7D, 7G). Starch and reducing sugars accumulate in the outer parenchyma cells (Tables 3,5 ), but in smaller amounts than in the non-galled leaves.

\section{Discussion}

Variations in histological complexity occur within each group of galls induced by the same taxon. Simple galls, such as those induced by E. ulmi on 
leaves of $U$. minor, and those induced by an unidentified Eriophyidae on $M$. ibaguensis, have fewer histological alterations. Hyperplasia occurs both in simple and complex galls, being the unique histological process common to all studied systems. Storage tissues are absent in less complex galls. Therefore, the presence and types of storage tissues may indicate the complexity level of a gall.

Different colonial taxa manipulate host-plant tissues differently

Current results have shown that histological patterns determined by each galling taxon also occur in colonial galls. However, the feeding habit of gall inducers alone does not explain these patterns. In fact, distinct groups of superficial-sucking gall inducers, i.e., nematodes and eriophyids, have different structural peculiarities.

The unprecedented comparisons among the three phylogenetically distant groups of gall-inducers, using histological, histometric, and histochemical tools, have shown that aphid galls have the most extensive range of histological alterations when compared to nematode and eriophyid galls. Aphid galls may have different levels of complexity (Álvarez et al. 2013), but all usually show hyperplasia, hypertrophied parenchyma cells and phloem bundles, and accumulate reducing sugars. Hypertrophy of the vascular bundles is expected in aphid galls, because the phloem is their food source (Wool et al. 1999), and directly receives the stimuli of gall induction. However, the orientation of the vascular bundles is maintained, and the stylets of the inducers may cross the xylem to suck the phloem sap (Álvarez et al. 2009). In addition, the two rows of vascular bundles observed in galls of $G$. utricularia have the 
same overall vascular organization as the control midrib (Álvarez 2011, 2012), as occurs in other aphid galls (Wool et al. 1999; Álvarez et al. 2014; Liu et al. 2014). Therefore, the complexity of aphid galls also depends on the complexity of the structure of the host organ. The presence of storage tissues, holes in the inner epidermis (Álvarez 2011, 2012; Álvarez et al. 2014), and mechanical tissues (Álvarez et al. 2009, 2016; Kurzfeld-Zexer et al. 2015) are other indicators of the complexity of aphid galls. The colonial galls induced by aphids are histologically similar to galls induced by solitary phloem-sucking gall inducers such as members of Psylloidea (Larew 1981; Bronner 1992; Dias et al. 2013; Carneiro and Isaias 2014, 2015; Carneiro et al. 2014), but the presence of several gall inducers per chamber increases the degree of hyperplasia and cell hypertrophy.

The nematode galls have shown a wide range of histological alterations, including the formation of a nutritive tissue with promeristematic features namely, the capability of differentiating several cell types - a novelty in comparison to the other gall systems. All nematode galls are formed by hyperplasia and homogenization of the parenchyma (Goodey 1939, 1948; Watson and Shorthouse 1979; Skinner et al. 1980), but these changes show no clear relationship to the cell size in nematode galls. The redifferentiation of cells in nematode gall developmental sites may result in larger (Goodey 1948; Bird 1961; Watson and Shorthouse 1979; Yousif 1979; Skinner et al. 1980), similarsized (Goodey 1939; Watson and Shorthouse 1979; Skinner et al. 1980) or smaller cells (Goodey 1948) in relation to the controls. The study of galls induced by $D$. gallaeformans reinforced the ability of gall-inducing nematodes to manipulate feeding cells in several ways, forming several types of nutritive 
tissues. Nutritive cells of galls of $D$. gallaeformans are smaller than the control cells, in concordance with their redifferentiation toward a meristematic status. The accumulation of reducing sugars and proteins, and the cytological features of these cells configure them as a typical nutritive tissue (TNT) (sensu Kostoff and Kendall 1929), as they are used directly for nematode feeding. The diversity of nematode galls is observed mainly in their nutritive structures, which may be giant polynucleated cells, syncytia, tissues with uninucleate or polynucleate cells (Dropkin 1969; Weischer and Wyss 1976; Meyer 1987; Wyss 1997), or a meristematic nutritive tissue (Goodey 1948; Ferreira et al. submitted; this work). Starch may sometimes accumulate in the outer parenchyma, and form a 'common storage tissue' (CST). The differentiation of mechanical and other specialized tissues is rare in nematode galls. However, a neoformed collenchyma was reported in galls of Anguina balsamophila on Wyethia amplexicaulis (Goodey 1948).

Galls of Eriophyidae members are less histologically complex than the nematode and aphid galls. In addition, current results demonstrated that eriophyid galls may have distinct complexity levels, as seen by the diversity of storage tissues they have. The galls induced on M. ibaguensis may be called 'filzgalls' (sensu Mani 1964), for they have homogeneous cells, with little modification from the non-galled mesophyll, and are covered with a denser indumentum (Larew 1981). Even though an outer CST with starch is present in both eriophyid galls studied here, a TNT with proteins occurs only in $A$. tristriata - Juglans regia galls. The vacuolated epidermal cells with reducing sugars are the feeding sites for eriophyids in M. ibaguensis, but they are not considered a TNT because their cells have a non-granulose cytoplasm and the nucleus is not 
prominent. Finally, the simultaneous ontogenetic processes (homogenization, hypertrophy, hyperplasia, and differentiation of TNT) of $A$. tristriata galls characterize these galls as more complex structures than the galls of $M$. ibaguensis (with only homogenization and neoformation of emergences). Neoformation of specialized tissues, other than the CST or the TNT, is not commonly observed in eriophyid galls (see Kendall 1930; Larew 1981; Westphal et al. 1981; Moura et al. 2008, 2009). An exception is the galls of Eriophyes ulmicola on Ulmus campestris, the only eriophyid gall with mechanical tissue that has been studied. These galls represent the "maximum histocytological differentiation" of the group (Meyer 1987).

Storage tissues are present especially in complex galls

Storage cells with lipids, proteins, starch or reducing sugars occur widely in plants (Evert 2006), as well as in galls (Bird 1961; Bronner 1992; Rohfritsch 1992; Oliveira and Isaias 2010; Ferreira et al. 2013; Vecchi et al. 2013). Considering the accumulated metabolites, the location of the storage cells, and whether or not they are the direct feeding site of the inducers, we defined three types of storage tissues, present in galls induced by eriophyids, aphids and nematodes: the TNT, typical nutritive tissues; the CST, common storage tissues; and the NLT, nutritive-like tissues, with different levels of activity and functions (Table 3). Current proposal on terminological standardization will facilitate the direct and precise reference of storage cells in future developmental studies.

TNT are commonly induced by chewing and scraping galling insects (Kostoff and Kendall 1929; Larew 1981; Bronner 1992; Ferreira and Isaias 
2013), and their cells are the direct feeding sites of the galling herbivores.

These cells are adjacent to the gall chamber, and may store lipids, proteins and/or reducing sugars. The TNT cells are usually recognized by their granulose cytoplasm and prominent nucleus, and also occur in galls induced by nematodes (Goodey 1948; Bird 1961; Dropkin 1969; Ferreira et al. submitted), such as those of $D$. gallaeformans, and in complex galls induced by eriophyids (Kendall 1930; Westphal et al. 1981; Moura et al. 2009), such as those of $A$. tristriata. Eriophyid galls in M. ibaguensis do not differentiate a TNT, an aspect of the relative simplicity of these filzgalls.

The CST is present in the outer layers of the eriophyid and nematode galls, and its cells have peripheral cytoplasm and should mobilize starch to reducing sugars for gall structural maintenance, as is commonly true for insect galls (Oliveira et al. 2010; Ferreira and Isaias 2013, 2014). The CST is also present in galls induced by phloem-sucking insects (Álvarez et al. 2009, 2013; Oliveira and Isaias 2010; Isaias et al. 2011; Álvarez 2011; Carneiro et al. 2014).

Sometimes, the storage cells have evident cytoplasmic activity, with cytoplasm granulation and a prominent nucleus, similar to those of the TNT, as observed in hemipteran galls (Carneiro and Isaias 2014, 2015; Richardson et al. 2016). However, they are here termed the NLT (Table 3), as they are not the direct feeding sites of the gall inducers (Richardson et al. 2016). Based on current results and literature on Psylloidea (Oliveira and Isaias 2010; Oliveira et al. 2010; Carneiro and Isaias 2014, 2015) and Aphididae galls (Alvarez et al. 2009, 2013; Richardson et al. 2016), the arrangement of storage tissues in galls induced by phloem-sucking insects should be similar. The most complex galls should have a NLT near the gall chamber and surrounding vascular bundles, 
and an outer CST, as observed in G. utricularia galls. The simpler galls should have no storage tissues, as observed in E. ulmi galls, or only a CST. The differences in hyperplasia and hypertrophy rates occurring on colonial (aphid) and solitary (psylloid) galls should reflect direct responses to the number of inducers and their influence on gall growth rates, which is yet to be evaluated.

As galls are usually sinks of photoassimilates (Larson and Whitham 1991; Inbar et al. 1995; Castro et al. 2012; Fleury et al. 2015), storage cells will differentiate in galls capable of draining a large amount of photoassimilates. The degree of starch accumulation in cortical tissues of galls is related to the strength of the sinks (Jones and Payne 1977; Kellow et al. 2004), which is directly influenced by the size of the colony. We have shown here that the histologically simplest galls may lack storage tissues, such as the galls of $E$. ulmi; they are presumed to be weaker sinks, draining fewer photoassimilates than the complex galls.

\section{Conclusions}

We have demonstrated that more complex galls, namely, those with more histological, histochemical and histometric alterations, have more specialized storage tissues than simpler galls. In addition, the distinct levels of complexity are not taxa-related, even though eriophyid galls are usually simpler than nematode and aphid galls. Even though a wider range of histological processes is usually required during the development of aphid galls, the nematodes have a broad capability for manipulating meristematic sites. This capability culminates in more-specialized typical nutritive tissues (TNT) in galls induced by nematodes, where meristematic nutritive sites, syncytial areas, or 
giant polynucleate cells may occur, depending on the inducing species. Independently of the galling taxa, the data from the literature refer to similar storage tissues with different names, and to different storage tissues with similar names. We revisited this nomenclature and proposed the current standardization. Accordingly, the storage tissues in galls may be divided into typical nutritive tissues (TNT), common storage tissues (CST), and nutritive-like tissues (NLT). Galls with TNT and NLT are more complex than those where only CST or no storage tissues occur.

\section{Acknowledgements}

We thank the Fundação de Amparo à Pesquisa do Estado de Minas Gerais (FAPEMIG) and the Conselho Nacional de Desenvolvimento Científico e Tecnológico (CNPq) for financial support. The Coordenação de Aperfeiçoamento de Pessoal de Nível Superior (CAPES) provided the first author's doctoral scholarships in Brazil and Spain (99999.003956/2015-06). Our gratitude to Dr. Nicolas Pérez-Hidalgo for helping in field sampling and identifying galls in Spain; to M.Sc. André Portugal-Santana, Parque Estadual Serra Verde (PESV-IEF-MG), Parque Municipal das Mangabeiras, and Estação Ecológica of UFMG for supporting field sampling of galls in Brazil; and to Janet Reid for English language revision.

\section{Reference list}

Álvarez, R. 2011. Initial stages in the formation of galls induced by Geoica utricularia in Pistacia terebinthus leaflets: origin of the two vascular bundles 
which characterize the wall of the galls. Am. J. Plant Sci. 2: 175-179. doi:10.4236/ajps.2011.22019.

Álvarez, R. 2012. Microscopic study of the walls of galls induced by Geoica utricularia and Baizongia pistaciae in Pistacia terebinthus: a contribution to the phylogeny of Fordini. Arthropod Plant Interact. 6: 137-145. doi:10.1007/s11829011-9154-3.

Álvarez, R., Encina, A., and Pérez-Hidalgo, N. 2009. Histological aspects of three Pistacia terebinthus galls induced by three different aphids: Paracletus cimiciformis, Forda marginata and Forda formicaria. Plant Sci. 176: 303-314. doi:10.1016/j.plantsci.2008.11.006.

Álvarez, R., González-Sierra, S., Candelas, A., and Martinez, J.J.I. 2013.

Histological study of galls induced by aphids on leaves of Ulmus minor: Tetraneura ulmi induces globose galls and Eriosoma ulmi induces pseudogalls. Arthropod Plant Interact. 7: 643-650. doi:10.1007/s11829-013-9278-8.

Álvarez, R., Molist, P., González-Sierra, S., Martinez, J.J.I., and Nieto-Nafría, J.M. 2014. The histo structure of galls induced by aphids as a useful taxonomic character: the case of Rectinasus (Hemiptera, Aphididae, Eriosomatinae).

Zootaxa 3861: 487-492. doi:10.11646/zootaxa.3861.5.6.

Álvarez, R., Martinez, J.J.I., Muñoz-Viveros, A.L., Molist, P., Abad-González, J., and Nieto-Nafría, J.M. 2016. Contribution of gall microscopic structure to taxonomy of gallicolous aphids. Plant Biol. (Stuttg.) 8: 868-875. doi:10.1111/plb.12475.

Bird, A.F. 1961. The ultrastructure and histochemistry of a nematode-induced giant cell. J. Biophys. Biochem. Cytol. 11: 701-715. doi:10.1083/jcb.11.3.701. 
Bronner, R. 1992. The role of nutritive cells in the nutrition of cynipids and cecidomyiids. In Biology of insect-induced galls. Edited by J.D. Shorthouse and O. Rohfritsch. Oxford University Press, New York. pp. 118-140.

Carneiro, R.G.S., and Isaias, R.M.S. 2014. Cytological cycles and fates in Psidium myrtoides are altered towards new cell metabolism and functionalities by the galling activity of Nothotrioza myrtoidis. Protoplasma 252: 637-646. doi:10.1007/s00709-014-0709-x.

Carneiro, R.G.S., and Isaias, R.M.S. 2015. Gradients of metabolite accumulation and redifferentiation of nutritive cells associated with vascular tissues in galls induced by sucking insects. AoB Plants 7: plv086. doi:10.1093/aobpla/plv086.

Carneiro, R.G.S., Castro, A.C., and Isaias, R.M.S. 2014. Unique histochemical gradients in a photosynthesis-deficient plant gall. S. Afr. J. Bot. 92: 97-104. doi:10.1016/j.sajb.2014.02.011.

Castro, A.C., Oliveira, D.C., Moreira, A.S.F.P., Lemos-Filho, J.P., and Isaias, R.M.S. 2012. Source-sink relationship and photosynthesis in the horn-shaped gall and its host plant Copaifera langsdorffii Desf. (Fabaceae). S. Afr. J. Bot. 83: 121-126. doi:10.1016/j.sajb.2012.08.007.

Dias, G.G., Ferreira, B.G., Moreira, G.R.P., and Isaias, R.M.S. 2013.

Developmental pathway from leaves to galls induced by a sap-feeding insect on Schinus polygamus (Cav.) Cabrera (Anacardiaceae). An. Acad. Bras. Ciências 85: 187-200. doi:10.1590/S0001-37652013000100010.

Dropkin, V.H. 1969. Cellular responses of plants to nematode infections. Ann. Rev. Phytopathol. 7: 101-122. doi:10.1146/annurev.py.07.090169.000533. 
Evert, R.F. 2006. Esau's plant anatomy: meristems, cells, and tissues of the plant body: their structure, function and development. John Wiley \& Sons, Inc., Hoboken. $3^{\text {rd }}$ edn.

Ferreira, B.G., and Isaias, R.M.S. 2013. Developmental stem anatomy and tissue redifferentiation induced by a galling Lepidoptera on Marcetia taxifolia (Melastomataceae). Botany 91: 752-760. doi:10.1139/cjb-2013-0125.

Ferreira, B.G., and Isaias, R.M.S. 2014. Floral-like destiny induced by a galling Cecidomyiidae on the axillary buds of Marcetia taxifolia (Melastomataceae). Flora 209: 391-400. doi:10.1016/j.flora.2014.06.004.

Ferreira, B.G., Avritzer, S.C., and Isaias, R.M.S. Submitted. Indeterminate growth in galls induced by Ditylenchus gallaeformans (Nematoda) on Miconia spp. (Melastomataceae) and long-distance developmental impacts. Flora.

Ferreira, B.G., Carneiro, R.G.S., and Isaias, R.M.S. 2015. Multivesicular bodies differentiate exclusively in nutritive fast-dividing cells in Marcetia taxifolia galls. Protoplasma 252: 1275-1283. doi:10.1007/s00709-015-0759-8.

Fleury, G., Ferreira, B.G., Oliveira, D.C., Soares, G.L.G., and Isaias, R.M.S. 2015. Elucidating the determination of the rosette galls induced by Pisphondylia brasiliensis Couri \& Maia 1992 (Cecidomyiidae) on Guapira opposita (Vell.) Reitz (Nyctaginaceae). Aust. J. Bot. 63: 608-617. doi:10.1071/BT15106.

Goodey, J.B. 1939. The structure of the leaf galls of Plantago lanceolata L. induced by Anguillulina dipsaci (Kühn) Gerv. \& v. Ben. J. Helminthol. 17: 183190. doi:10.1017/S0022149X00031230. 
Goodey, J.B. 1948. The galls caused by Anguillulina balsamophila (Thorne) Goodey on the leaves of Wyethia amplexicaulis Nutt. and Balsamorhiza sagittata Nutt. J. Helminthol. 22: 109-116. doi:10.1017/S0022149X00032223.

Inbar, M., Eshel, A., and Wool, D. 1995. Interspecific competition among phloem-feeding insects mediated by induced host-plant sinks. Ecology 76 : 1506-1515. doi:10.2307/1938152.

Isaias, R.M.S., Oliveira, D.C., and Carneiro, R.G.S. 2011. Role of Euphalerus ostreoides (Hemiptera: Psylloidea) in manipulating leaflet ontogenesis of Lonchocarpus muehlbergianus (Fabaceae). Botany 89: 581-592. doi:10.1139/b11-048.

Jensen, W.A. 1962. Botanical histochemistry: principles and practices. W.H. Freeman and Co., San Francisco.

Johansen, D.A. 1940. Plant microtechnique. McGraw-Hill Book Co., New York. Jones, M.G.K., and Payne, H.L. 1977. The structure of syncytia induced by the phytoparasitic nematode Nacobbus aberrans in tomato roots, and the possible role of plasmodesmata in their nutrition. J. Cell Sci. 33: 299-313. Available from http://jcs.biologists.org/content/23/1/299 [accessed 27 June 2016].

Karnovsky, M.J. 1965. A formaldehyde-glutaraldehyde fixative of high osmolarity for use in electron microscopy. J. Cell Biol. 27: 137-138.

Kellow, A.V., Sedgley, M., and van Heeswijck, R. 2004. Interaction between Vitis vinifera and grape Phylloxera: Changes in root tissue during nodosity formation. Ann. Bot. 93: 581-590. doi: 10.1093/aob/mch082. 
Kendall, J. 1930. The structure and development of certain eriophyid galls. Z. Parasitenk. 2: 477-501. doi:10.1007/BF02119368.

Kostoff, D., and Kendall, J. 1929. Studies on the structure and development of certain Cynipid galls. Biol. Bull. 56: 402-458. doi:10.2307/1537132.

Kraus, J.E., and Arduin, M. 1997. Manual Básico de Métodos em Morfologia Vegetal. Editora da Universidade Federal Rural do Rio de Janeiro, Seropédica.

Kurzfeld-Zexer, L., Lev-Yadun, S., and Inbar, M. 2015. One aphid species induces three gall types on a single plant: Comparative histology of one genotype and multiple extended phenotypes. Flora 210: 19-30. doi:10.1016/j.flora.2014.10.007.

Kutsukake, M., Meng, X.-Y., Katayama, N., Nikoh, N., Shibao, H., and Fukatsu, T. 2012. An insect-induced novel plant phenotype for sustaining social life in a closed system. Nature Comm. 3: 1187-1194. doi:10.1038/ncomms2187.

Larew, H.G. 1981. A comparative anatomical study of galls caused by the major cecidogenetic groups, with special emphasis on the nutritive tissue. Ph.D. thesis, Entomology, Oregon State University, Corvallis, U.S.A.

Larson, K.C., and Whitham, T.G. 1991. Manipulation of food resources by a gall-forming aphid: the physiology of sink-source interactions. Oecologia 88: 15-21. doi:10.1007/BF00328398.

Liu, P., Yang, Z.X., Chen, X.M., and Foottit, R.G. 2014. The effect of the gallforming aphid Schlechtendalia chinensis (Hemiptera: Aphididae) on leaf wing ontogenesis in Rhus chinensis (Sapindales: Anacardiaceae). Ann. Entomol. Soc. Am. 107: 242-250. doi:10.1603/AN13118. 
Mani, M.S. 1964. Ecology of plant galls. Dr. W. Junk Publishers, The Hague.

Moura, M.Z.D., Soares, G.L.G., and Isaias, R.M.S. 2008. Species-specific changes in tissue morphogenesis induced by two arthropod leaf gallers in Lantana camara L. (Verbenaceae). Aust. J. Bot. 56: 153-160. doi:10.1071/BT07131.

Moura, M.Z.D., Soares, G.L.G., and Isaias, R.M.S. 2009. Ontogênese da folha e das galhas induzidas por Aceria lantanae Cook (Acarina: Eriophyidae) em Lantana camara L. (Verbenaceae). Rev. Bras. Bot. 32: 271-282. doi:10.1590/S0100-84042009000200007.

Muñoz-Viveros, A.L., Martinez, J.J.I., Molist, P., González-Sierra, S., Julián, P.G., and Álvarez, R. 2014. Microscopic study of galls induced by three species of Geopemphigus (Hemiptera: Aphididae: Eriosomatinae) on Pistacia mexicana. Arthropod Plant Interact. 8: 531-538. doi:10.1007/s11829-014-9333-0.

Oliveira, D.C., and Isaias, R.M.S. 2010. Cytological and histochemical gradients induced by a sucking insect in galls of Aspidosperma australe Arg. Muell (Apocynaceae). Plant Sci. 178: 350-358. doi:10.1016/j.plantsci.2010.02.002.

Oliveira, D.C., Magalhães, T.A., Carneiro, R.G.S., Alvim, M.N., and Isaias, R.M.S. 2010. Do Cecidomyiidae galls of Aspidosperma spruceanum (Apocynaceae) fit the pre-established cytological and histochemical patterns? Protoplasma 242: 81-93. doi:10.1007/s00709-010-0128-6.

Oliveira, D.C., Carneiro, R.G.S., Magalhães, T.A., and Isaias, R.M.S. 2011. Cytological and histochemical gradients on two Copaifera langsdorffii Desf. (Fabaceae) - Cecidomyiidae gall systems. Protoplasma 248: 829-837. doi: 10.1007/s00709-010-0258-X. 
Oliveira, D.C., Isaias, R.M.S., Fernandes, G.W., Ferreira, B.G., Carneiro, R.G.S., and Fuzaro, L. 2016. Manipulation of host plant cells and tissues by gall-inducing insects and adaptive strategies used by different feeding guilds. J. Insect Physiol. 84: 103-113. doi:10.1016/j.jinsphys.2015.11.012.

Paiva, J.G.A., Fank-de-Carvalho, S.M., Magalhães, M.P., and Graciano-Ribeiro, D. 2006. Verniz vitral incolor $500 \AA$ : uma alternativa de meio de montagem economicamente viável. Acta Bot. Bras. 20: 257-264. doi:10.1590/S010233062006000200002.

Price, P.W., Fernandes, G.W., and Waring, G.L. 1987. Adaptive nature of insect galls. Environ. Entomol. 16: 15-24.

Richardson, R.A., Body, M., Warmund, M.R., Schultz, J.C., and Appel, H.M. 2016. Morphometric analysis of young petiole galls on the narrow-leaf cottonwood, Populus angustifolia, by the sugarbeet root aphid, Pemphigus betae. Protoplasma. doi:10.1007/s00709-015-0937-8.

Rohfritsch, O. 1992. Patterns in gall development. In Biology of insect-induced galls. Edited by J.D. Shorthouse and O. Rohfritsch. Oxford University Press, New York. pp. 60-86.

Sass, J.E. 1951. Botanical microtechnique. lowa State College Press, Ames. Skinner, J.A., Orr, C.C., and Robinson, A.F. 1980. Histopathogenesis of the galls induced by Nothanguina phyllobia in Solanum elaeagnifolium. J. Nematol.

12: 141-150. Available from:

http://www.ncbi.nlm.nih.gov/pmc/articles/PMC2618007 [accessed 27 June 2016]. 
Sliva, M.D., and Shorthouse, J.D. 2006. Comparison of the development of stem galls induced by Aulacidea hieracii (Hymenoptera: Cynipidae) on hawkweed and by Diplolepis spinosa (Hymenoptera: Cynipidae) on rose. Can. J. Bot. 84: 1052-1074. doi:10.1139/b06-068.

Stone, G.N., and Schonrogge, N. 2003. The adaptive significance of insect gall morphology. Trends Ecol. Evol. 18: 512-522. doi:10.1016/S0169$5347(03) 00247-7$.

Ventrella, M.C., Almeida, A.L., Nery, L.A., and Coelho, V.P.M. 2013. Métodos histoquímicos aplicados às sementes. Editora UFV, Viçosa. Available from: http://www.bibliotecaflorestal.ufv.br/handle/123456789/5158 [accessed 27 June 2016].

Vecchi, C., Menezes, N.L., Oliveira, D.C., Ferreira, B.G., and Isaias, R.M.S. 2013. The redifferentiation of nutritive cells in galls induced by Lepidoptera on Tibouchina pulchra (Cham.) Cogn. reveals predefined patterns of plant development. Protoplasma 250: 1363-1368.

Watson, A.K., and Shorthouse, J.D. 1979. Gall formation on Cirsium arvense by Ditylenchus dipsaci. J. Nematol. 11: 16-22. Available from:

http://www.ncbi.nlm.nih.gov/pmc/articles/PMC2617925/ [accessed 27 June 2016].

Weischer, B., and Wyss, U. 1976. Feeding behaviour and pathogenicity of Xiphinema index on grapevine roots. Nematologica 22: 319-325. doi:10.1163/187529276X00607.

Westphal, E., Bronner, R., and Le Ret, M. 1981. Changes in leaves of susceptible and resistant Solanum dulcamara infested by the gall mite 
Eriophyes cladophthirus (Acarina, Eriophyoidea). Can. J. Bot. 59: 875-882. doi:10.1139/b81-122

Wool, D., Aloni, R., Ben-Zvi, O., and Wollberg, M. 1999. A galling aphid furnishes its home with a built-in pipeline to the host food supply. Entomol. Exper. Appl. 91: 183-186. doi:10.1046/j.1570-7458.1999.00482.x.

Wyss, U. 1997. Root Parasitic Nematodes: An Overview. In Cellular and molecular aspects of plant-nematode interactions. Edited by C. Fenoll, F.M.W. Grundler, and S.A. Ohl. Kluwer Academic Publishers, Dordrecht. pp. 5-22. Yousif, G.M. 1979. Histological responses of four leguminous crops infected with Meloidogyne incognita. J. Nematol. 11: 395-401. Available from: http://www.ncbi.nlm.nih.gov/pmc/articles/PMC2617974/ [accessed 27 June 2016]. 


\section{Tables}

Table 1. Galls studied.

\begin{tabular}{llll}
\hline Gall inducer & Group & Host plant & Sampling area \\
Eriosoma ulmi & Aphididae & Ulmus minor & León, Spain \\
Geoica utricularia & Aphididae & Pistacia terebinthus & León, Spain \\
Ditylenchus gallaeformans & Nematoda & Miconia albicans & Belo Horizonte, Brazil \\
Ditylenchus gallaeformans & Nematoda & Miconia ibaguensis & Belo Horizonte, Brazil \\
Unidentified & Eriophyidae & Miconia ibaguensis & Belo Horizonte, Brazil \\
Aceria tristriata & Eriophyidae & Juglans regia & León, Spain \\
\hline
\end{tabular}


Table 2. Histometry and histochemistry in controls and aphid galls.

\begin{tabular}{|c|c|c|c|c|}
\hline & \multicolumn{2}{|c|}{ E. ulmi - U. minor } & \multicolumn{2}{|c|}{ G. utricularia - P. terebinthus } \\
\hline & Control & Gall & Control & Gall \\
\hline Wall thickness & $196.74 \mathrm{~b}$ & $447.33 \mathrm{a}$ & $414.29 \mathrm{~b}$ & $660.10 \mathrm{a}$ \\
\hline \multicolumn{5}{|l|}{ Adaxial epidermis } \\
\hline Cell area & $408.45 \mathrm{~b}$ & $1086.43 \mathrm{a}$ & $207.99 \mathrm{~b}$ & $330.16 \mathrm{a}$ \\
\hline \multicolumn{5}{|l|}{ Parenchyma } \\
\hline Cell layers & $5.84 \mathrm{~b}$ & $7.35 \mathrm{a}$ & $14.20 \mathrm{~b}$ & $26.28 \mathrm{a}$ \\
\hline \multicolumn{5}{|l|}{ Cell area } \\
\hline Adaxial & $441.99 \mathrm{~b}$ & \multirow[b]{2}{*}{$3223.23 \mathrm{a}$} & $288.68 b$ & 485.99 a \\
\hline Abaxial & $223.71 b$ & & $234.99 \mathrm{~b}$ & $659.40 \mathrm{a}$ \\
\hline Starch & + & - & + & ++ \\
\hline Reducing sugars & + & + & + & ++ \\
\hline Proteins & +++ & + & + & + \\
\hline Oil & & - & + & - \\
\hline \multicolumn{5}{|l|}{ Phloem } \\
\hline Main bundle & $49.10 \mathrm{~b}$ & 86.29 a & $169.44 \mathrm{a}$ & $97.76 \mathrm{~b}$ \\
\hline Supernumerary bundle & NA & NA & $32.09 \mathrm{~b}$ & $77.64 \mathrm{a}$ \\
\hline \multicolumn{5}{|l|}{ Xylem } \\
\hline Main bundle & $27.70 \mathrm{~b}$ & $59.09 \mathrm{a}$ & $92.22 \mathrm{a}$ & $33.11 \mathrm{~b}$ \\
\hline Supernumerary bundle & NA & NA & $20.11 \mathrm{a}$ & $30.60 \mathrm{a}$ \\
\hline \multicolumn{5}{|l|}{ Abaxial Epidermis } \\
\hline Cell area & $260.79 b$ & 1377.98 a & $127.64 \mathrm{a}$ & $156.12 \mathrm{a}$ \\
\hline \multicolumn{5}{|c|}{ The comparisons were performed between the control and the respective gall. } \\
\hline \multicolumn{5}{|c|}{$\begin{array}{l}\text { Data followed by different letters are statistically different. Units: wall thickness } \\
(\mu \mathrm{m}) \text {; cell area }\left(\mu \mathrm{m}^{2}\right) \text {; cell layers (number). Histochemistry results: (-) absence; }\end{array}$} \\
\hline ), ( & 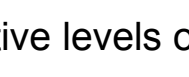 & 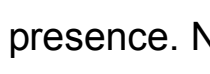 & 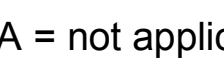 & \\
\hline
\end{tabular}


Table 3. Classification of storage tissues in the galls studied, based on reserves, cytological features and whether it is a feeding tissue.

\begin{tabular}{|c|c|c|c|c|c|c|c|c|c|c|c|c|}
\hline & \multicolumn{4}{|c|}{ Aphididae } & \multicolumn{4}{|c|}{ Ditylenchus gallaeformans } & \multicolumn{4}{|c|}{ Eriophyidae } \\
\hline & \multicolumn{2}{|c|}{ E. ulmi } & \multicolumn{2}{|c|}{ G. utricularia } & \multicolumn{2}{|c|}{ on M. albicans } & \multicolumn{2}{|c|}{ on M. ibaguensis } & \multicolumn{2}{|c|}{ on M. ibaguensis } & \multicolumn{2}{|c|}{ Aceria tristriata } \\
\hline & End & Mph & OP & IP & OP & IP & OP & IP & Mph & $\mathrm{AbE}$ & OP & $\mathrm{IP}$ \\
\hline \multicolumn{13}{|l|}{ Reserves } \\
\hline Reducing sugars & ++ & - & + & ++ & - & +++ & - & +++ & - & ++ & + & + \\
\hline Starch & - & - & ++ & ++ & ++ & - & ++ & - & + & - & + & - \\
\hline Proteins & - & - & - & + & - & ++ & - & ++ & + & + & - & +++ \\
\hline Oil & - & - & - & - & - & - & - & - & + & - & - & ++ \\
\hline \multicolumn{13}{|l|}{ Cytological features } \\
\hline $\begin{array}{l}\text { Cytoplasm } \\
\text { granulation }\end{array}$ & - & - & - & + & - & + & - & + & - & - & - & + \\
\hline Prominent nucleus & - & - & - & + & - & + & - & + & - & - & - & + \\
\hline Feeding tissue & No & No & No & No & No & Yes & No & Yes & No & Yes & No & Yes \\
\hline Storage tissue type & - & - & CST & NLT & CST & TNT & CST & TNT & CST & - & CST & TNT \\
\hline
\end{tabular}

AbE: abaxial epidermis; CST: common storage tissue; End: endodermis; IP: inner parenchyma; Mph: mesophyll; NLT: nutritive-like tissue; OP: outer parenchyma; TNT: typical nutritive tissue. Histochemistry results: $(-)$ absent; $(+),(++) ;(+++)$ : semi-quantitative levels of presence. Cytological features: (-) absent; (+) present. 
Table 4. Histometry and histochemistry in controls and nematode galls.

\begin{tabular}{|c|c|c|c|c|}
\hline & \multicolumn{2}{|c|}{ D. gallaeformans - M. albicans } & \multicolumn{2}{|c|}{ D. gallaeformans - M. ibaguensis } \\
\hline & Control & Gall & Control & Gall \\
\hline $\begin{array}{l}\text { Wall thickness } \\
\text { Adaxial/outer } \\
\text { epidermis }\end{array}$ & $143.25 \mathrm{~b}$ & $302.12 \mathrm{a}$ & $174.09 \mathrm{~b}$ & $409.65 a$ \\
\hline Cell area & 604.65 a & $148.54 \mathrm{~b}$ & $237.82 \mathrm{a}$ & $168.11 \mathrm{~b}$ \\
\hline Trichomes & - & +++ & - & +++ \\
\hline Parenchyma & & & & \\
\hline $\begin{array}{l}\text { Cell layers } \\
\text { Cell area }\end{array}$ & $5.67 \mathrm{~b}$ & 15.39 a & $8.20 \mathrm{~b}$ & $20.2 \mathrm{a}$ \\
\hline Adaxial & $701.50 \mathrm{a}$ & $528.67 \mathrm{a}$ & $960.71 \mathrm{a}$ & $883.92 \mathrm{a}$ \\
\hline Abaxial & $139.61 \mathrm{~b}$ & $84.78 \mathrm{~b}$ & $312.81 \mathrm{~b}$ & $128.13 \mathrm{c}$ \\
\hline $\begin{array}{l}\text { Starch } \\
\text { Reducing }\end{array}$ & ++ & + & ++ & + \\
\hline sugars & + & +++ & + & +++ \\
\hline Proteins & + & + & + & + \\
\hline $\begin{array}{l}\text { Oil } \\
\text { Abaxial/nutritive } \\
\text { epidermis }\end{array}$ & + & - & + & - \\
\hline $\begin{array}{l}\text { Cell area } \\
\text { Trichomes }\end{array}$ & $\begin{array}{c}92.37 \mathrm{a} \\
++\end{array}$ & $\begin{array}{c}63.92 \mathrm{~b} \\
-\end{array}$ & $\begin{array}{c}151.77 \mathrm{a} \\
++\end{array}$ & $\begin{array}{c}113.83 \mathrm{~b} \\
-\end{array}$ \\
\hline
\end{tabular}

The comparisons were performed between the control and the respective gall.

Data followed by different letters are statistically different. Units: wall thickness $(\mu \mathrm{m})$; cell area $\left(\mu \mathrm{m}^{2}\right)$; cell layers (number). Histochemistry results: $(-)$ absence;

$(+),(++) ;(+++)$ : semi-quantitative levels of presence. 
Table 5. Histometry and histochemistry in controls and eriophyid galls.

\begin{tabular}{|c|c|c|c|c|}
\hline & \multicolumn{2}{|c|}{ Eriophyidae - M. ibaguensis } & \multicolumn{2}{|c|}{ A. tristriata - J. regia } \\
\hline & Control & Gall & Control & Gall \\
\hline $\begin{array}{l}\text { Wall thickness } \\
\text { Adaxial epidermis }\end{array}$ & $174.09 \mathrm{a}$ & $154.63 \mathrm{a}$ & $127.42 \mathrm{~b}$ & $782.06 \mathrm{a}$ \\
\hline $\begin{array}{l}\text { Cell area } \\
\text { Parenchyma }\end{array}$ & $237.82 \mathrm{a}$ & $328.17 \mathrm{a}$ & $241.07 \mathrm{~b}$ & $393.90 \mathrm{a}$ \\
\hline $\begin{array}{l}\text { Cell layers } \\
\text { Cell area }\end{array}$ & $8.20 \mathrm{a}$ & $7.60 \mathrm{a}$ & $5.80 \mathrm{~b}$ & $18.70 \mathrm{a}$ \\
\hline Adaxial & $960.71 \mathrm{a}$ & $319.02 \mathrm{~b}$ & $197.75 b$ & $1836.16 \mathrm{a}$ \\
\hline Abaxial & $312.81 \mathrm{a}$ & $351.48 \mathrm{a}$ & $136.56 \mathrm{~b}$ & $1720.31 \mathrm{a}$ \\
\hline Starch & ++ & + & ++ & + \\
\hline Reducing sugars & + & ++ & + & + \\
\hline Proteins & + & + & + & ++ \\
\hline $\begin{array}{l}\text { Oil } \\
\text { Abaxial epidermis }\end{array}$ & + & + & + & + \\
\hline $\begin{array}{l}\text { Cell area } \\
\text { Emergences }\end{array}$ & $\begin{array}{c}151.77 \mathrm{a} \\
+\end{array}$ & $\begin{array}{c}211.53 \mathrm{a} \\
+++\end{array}$ & $\begin{array}{c}162.09 \mathrm{~b} \\
-\end{array}$ & $\begin{array}{c}348.53 a \\
-\end{array}$ \\
\hline \multicolumn{5}{|c|}{ The comparisons were performed between the control and the respective gall. } \\
\hline \multicolumn{5}{|c|}{ Data followed by different letters are statistically different. Units: wall thickness } \\
\hline$(\mu \mathrm{m})$; cell area $(\mu$ & ell lavers & r). Histo & ry resu & sence; \\
\hline,$(++) ;(+++) . s$ & & ese & & \\
\hline
\end{tabular}




\section{Figure captions}

Figure 1. Non-galled leaf and leaf-rolling gall of Eriosoma ulmi on Ulmus minor. (A) Leaf-rolling gall, macroscopic view. (B) Transverse section of non-galled leaf. (C-E) Leaf-rolling gall, transverse sections. (C) Region similar to non-galled mesophyll. (D) Folding region, with homogenization of parenchyma, hyperplasia, cell hypertrophy, and hypertrophy of xylem and phloem. (E) Reducing sugars accumulated mainly in the area of vascular tissues (dotted line, brown precipitates) and endodermis (arrow). (F) Low accumulation of proteins in galls. (G) Accumulation of proteins in controls. Abbreviations: Ar: aerenchyma. En: endodermis. GC: gall chamber. HP: homogeneous parenchyma. NGL: non-galled leaf. Ph: phloem. PP: palisade parenchyma. Tr: trichome. VB: vascular bundle. Xy: xylem. Bars: (A) 5 mm. (B-G) $100 \mu \mathrm{m}$. Staining: safranin and fast green (B-D); Fehling's reagent (E); Ponceau 2R (FG).

Figure 2. Non-galled leaflet midrib and gall of Geoica utricularia on Pistacia terebinthus. (A, C-D) Globoid gall associated with midrib. (B-D) Transverse sections. (B) Midrib of non-galled leaflet (NGL), with main and supernumerary (arrow) vascular bundles. (C) Gall with main (MB) and supernumerary vascular bundles (SB), homogeneous parenchyma differentiated into inner (IP) and outer (OP) regions. Small holes (arrows) in the inner epidermis. Details of the main vascular bundles is shown in the box. (D) Reducing sugars accumulate abundantly in storage tissues (arrows). (E) Inner region of gall, with NutritiveLike (NL) cells, with starch accumulation. Small holes in inner epidermis (arrow). Detail of the supernumerary vascular bundle (SB). Abbreviations: GC: gall chamber. Ph: phloem. SD: secretory duct. Xy: xylem. Bars: (A) $1 \mathrm{~cm}$. (B-C) 
$100 \mu \mathrm{m}$. (D) $200 \mu \mathrm{m}$. (E) $50 \mu \mathrm{m}$. Staining: safranin-fast green (B-C, E); Fehling's reagent (D).

Figure 3. Galls of Ditylenchus gallaeformans on Miconia albicans. (A-B) Globoid galls induced on abaxial surface of M. albicans. (A) Older verrucous gall (arrow). (B) Younger gall. (C) Gall with overlapped curved emergences (arrow). (D) Transition zone between non-galled leaf with palisade and spongy parenchyma, and gall with homogeneous parenchyma and inner regions with nutritive tissue and young emergences. (E) Details of emergences and nutritive tissue of galls. The outer parenchyma has polyhedral cells and some idioblasts with druses (arrows). (F-G) Differences among cells of nutritive tissue, with denser cytoplasm and prominent nucleus, and outer parenchyma, with larger and vacuolated cells. Abbreviations: Cy: cytoplasm. HP: homogeneous parenchyma. LN: leafy neoformation. NGL: non-galled portion of leaf. Nm: nematodes. NT: nutritive tissue. Nu: nucleus. OP: outer parenchyma. PP: palisade parenchyma. SP: spongy parenchyma. Tr: arachnoid trichomes. Vc: vacuole. VT: vascular tissue. YE: young emergences. Bars: (A) $5 \mathrm{~cm}$. (B) $5 \mathrm{~mm}$. (C) $500 \mu \mathrm{m}$. (D) $100 \mu \mathrm{m}$. (E) $50 \mu \mathrm{m}$. (F) $20 \mu \mathrm{m}$. (G) $10 \mu \mathrm{m}$. Staining: safraninastra blue (C-E); toluidine blue (F-G).

Figure 4. Galls of Ditylenchus gallaeformans on Miconia albicans. Transverse sections. (A) Polarized light image, showing lignified trichomes and idioblasts with druses (arrow) in gall parenchyma. (B) Starch grains in outer parenchyma (arrows), but absent in the adjacent nutritive tissue. (C) Greater accumulation of reducing sugars in nutritive tissue, vascular bundles and young emergences of galls in comparison with the non-galled region of the leaf. Abbreviations: GC: gall chamber. NGL: non-galled region of leaf. Nm: nematodes. NT: nutritive 
tissue. OP: outer parenchyma. Tr: arachnoid trichomes. VB: vascular bundle. YE: young emergences. Bars: (A) $200 \mu \mathrm{m}$. (B) $50 \mu \mathrm{m}$. (C) $500 \mu \mathrm{m}$. Staining: safranin-astra blue (A); Lugol (B); Fehling's reagent (C).

Figure 5. Galls of Ditylenchus gallaeformans on Miconia ibaguensis. (A) Globoid verrucous galls (white arrow) induced on adaxial surface, with leafy neoformations (black arrow). (B-F) Transverse sections. (B) Gall with curved vascularized emergences (arrows) and leafy neoformation. (C) Details of mature and young emergences in a gall. (D) Detail of a mature emergence, with meristematic nutritive tissue in contact with nematodes, and collateral vascular bundle. (E) Proteins in nutritive tissues (arrows) and vascular bundles. (F) Greater accumulation of reducing sugars in nutritive tissue, vascular bundles and young emergences of galls. Abbreviations: GC: gall chamber. NGL: nongalled portion of leaf. NL: neoformed leaf. Nm: nematodes. NT: nutritive tissue. OP: outer parenchyma. Ph: phloem. PP: palisade parenchyma. SP: spongy parenchyma. Tr: stellate trichomes. VB: vascular bundle. YE: young emergences. Xy: xylem. Bars: (A) 5 mm. (B) $500 \mu \mathrm{m}$. (C, E, F) $200 \mu \mathrm{m}$. (D) 50 $\mu$ m. Staining: safranin-astra blue (B-D); Ponceau 2R (E), and Fehling's reagent $(\mathrm{F})$.

Figure 6. Gall of Eriophyidae on Miconia ibaguensis. (A-C) Blister-shaped galls, with overdifferentiated indumentum in abaxial region (C). (D-I) Transverse sections of galls. (D) Blister gall in continuity with non-galled leaf region (NGL). Several neoformed emergences are visible in abaxial region. (E-F) Gall with homogeneous parenchyma, neoformed emergences, and epidermis, where the eriophyids feed. (G) Polarized light image showing druses (arrows), but no lignified tissue. $(\mathrm{H})$ Reducing sugars in epidermis and emergences. (I) Starch 
(arrows) in homogeneous gall parenchyma. Abbreviations: Em: emergences.

Er: eriophyid. Ep: epidermis. GC: gall chamber. HP: homogeneous

parenchyma. NGL: leaf non-galled region. NT: nutritive tissue. OP: outer

parenchyma. Bars: (A) $1 \mathrm{~cm}$. (B) $4 \mathrm{~mm}$. (C) $2 \mathrm{~mm}$. (D) $500 \mu \mathrm{m}$. (E, H, I) $50 \mu \mathrm{m}$.

(F) $25 \mu \mathrm{m}$. (G) $200 \mu \mathrm{m}$. Staining: astra blue-safranin (D, G); toluidine blue (E-F);

Fehling's reaction $(\mathrm{H})$; Lugol $(\mathrm{I})$.

Figure 7. Gall of Aceria tristriata (Eriophyidae) on Juglans regia. (A, C-G)

Transverse sections of lenticular gall. (A) Gall with hypertrophied homogeneous parenchyma compared with non-galled leaf regions. The mites are present in the cavities (arrows). (B) Lenticular galls (arrow) on abaxial surface. (C) Chamber (dotted line) of the eriophyids, surrounded by a nutritive tissue. (D) Nutritive cells are perforated by eriophyids and appear disrupted (black arrow). Adjacent cells become nutritive (white arrows), with prominent nucleus and granulose cytoplasm. (E) Protein granules (arrowheads) detected in TNT, near the eriophyids. (F) Typical nutritive tissue. (G) Hypertrophied and vacuolated outer cell, with smaller nucleus. Abbreviations: Cy: cytoplasm. Er: eriophyids. HP: homogeneous parenchyma. NGL: leaf non-galled region. Nu: nucleus. PP: palisade parenchyma. SP: spongy parenchyma. TNT: typical nutritive tissue. Vc: vacuole. VB: vascular bundle. Bars: (A) $200 \mu \mathrm{m}$. (B) $5 \mathrm{~mm}$. (C, E) $100 \mu \mathrm{m}$. (D) $50 \mu \mathrm{m} .(F, G) 10 \mu \mathrm{m}$. Staining: safranin-fast green (A, C-D, F-G); Ponceau $2 R(E)$. 

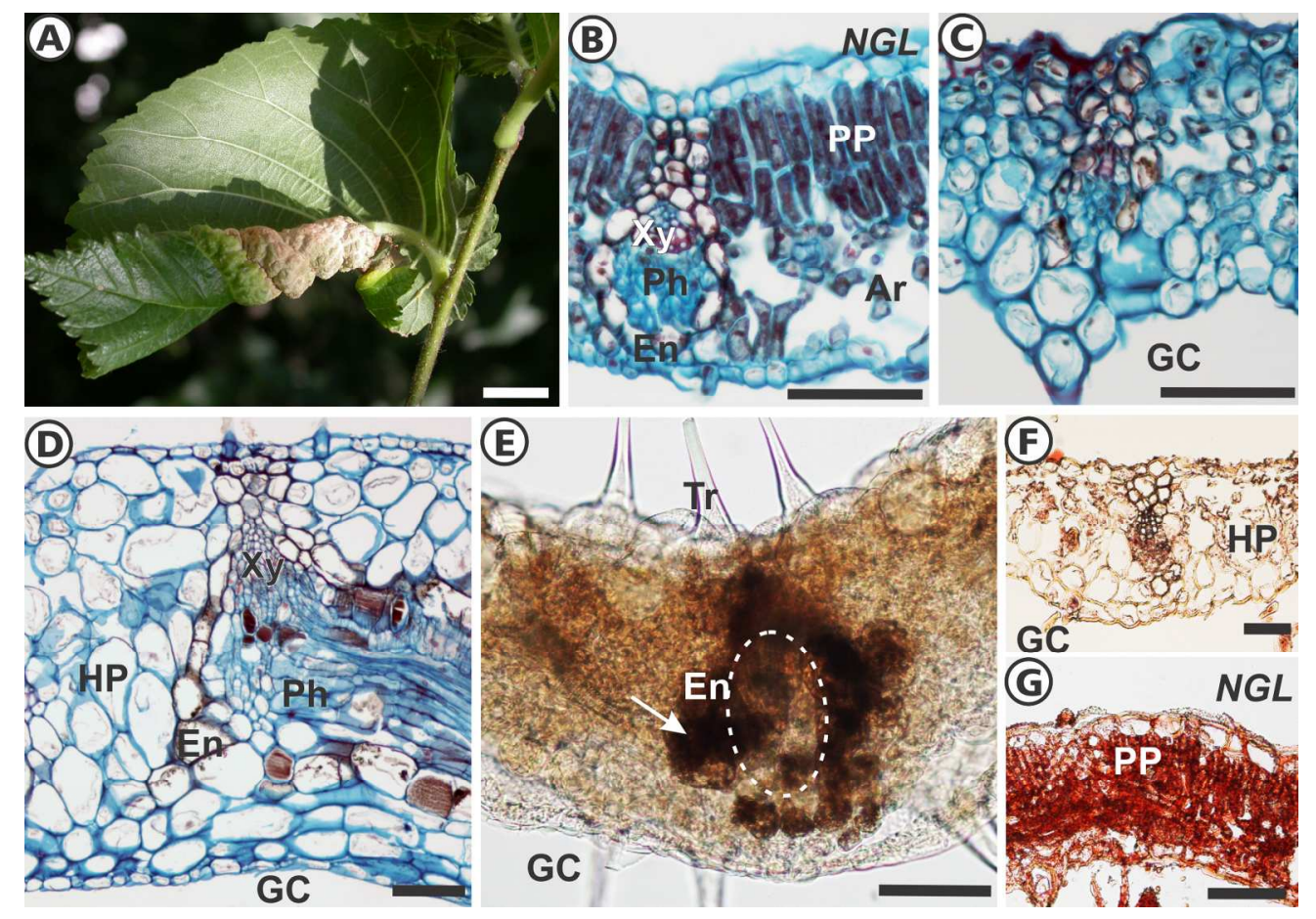

Fig. 1

Fig. 1

$170 \times 119 \mathrm{~mm}(300 \times 300 \mathrm{DPI})$ 

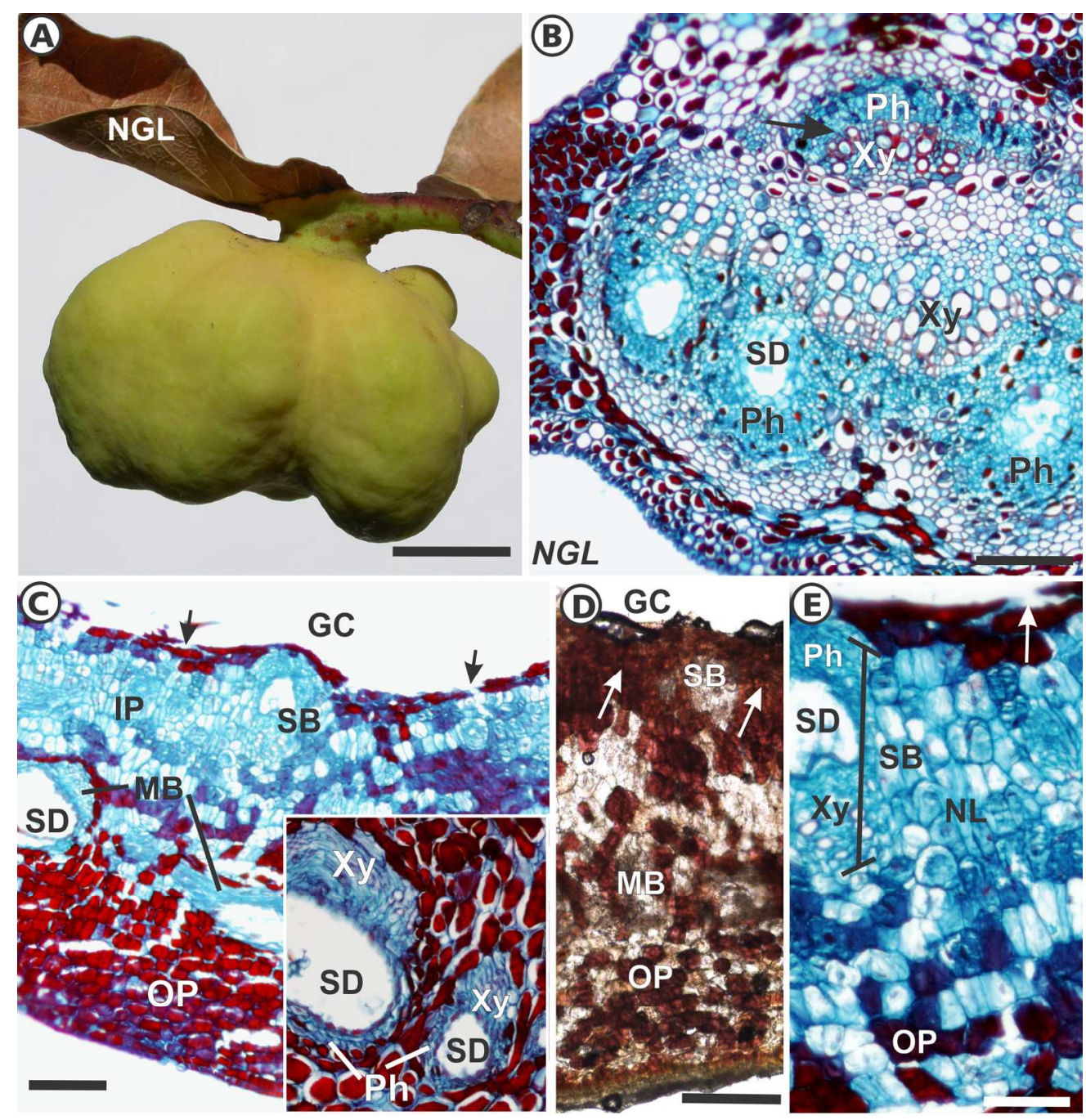

Fig. 2

Fig. 2

$163 \times 168 \mathrm{~mm}(300 \times 300 \mathrm{DPI})$ 

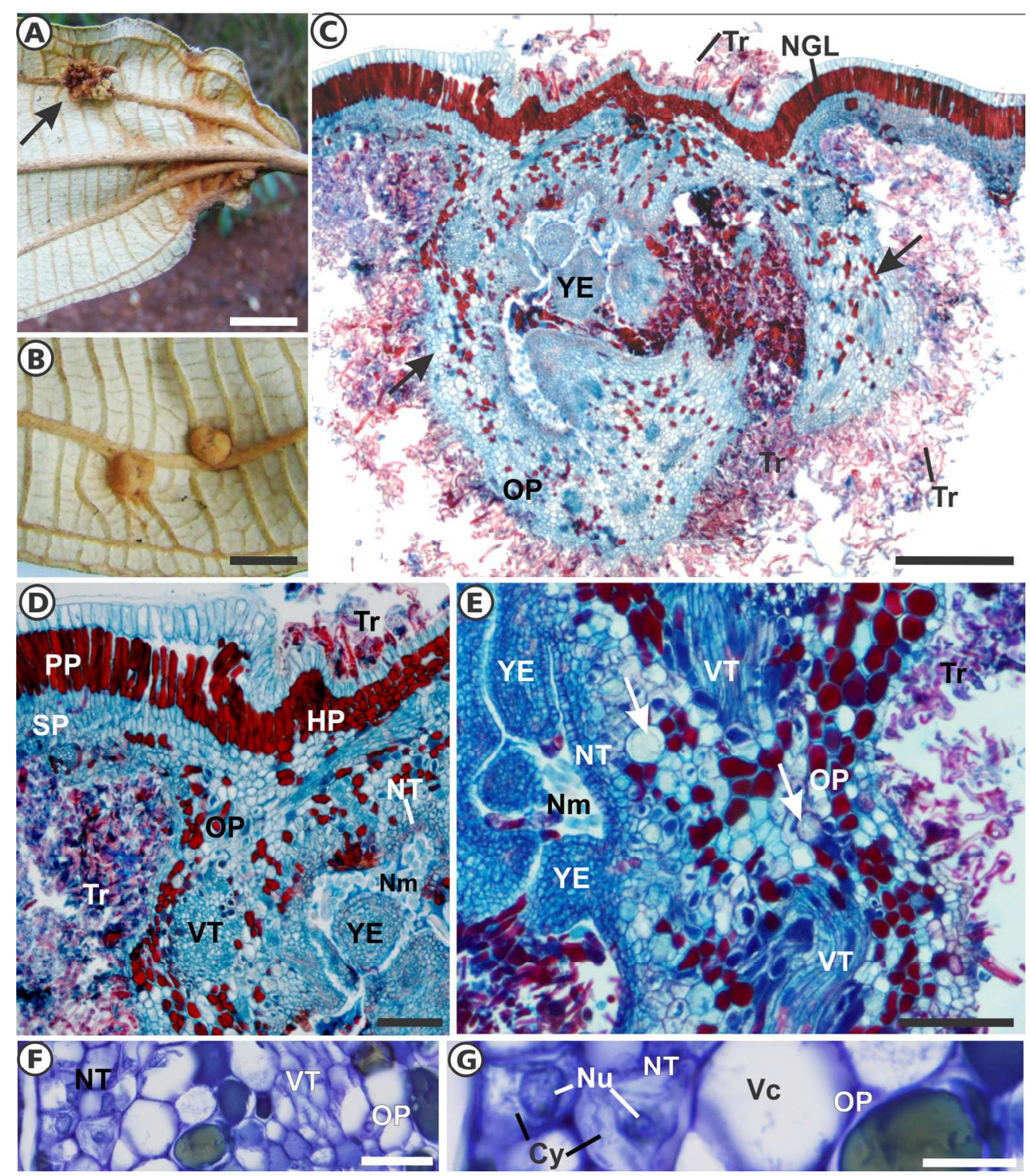

Fig. 3

Fig. 3

$178 \times 205 \mathrm{~mm}(300 \times 300$ DPI $)$ 

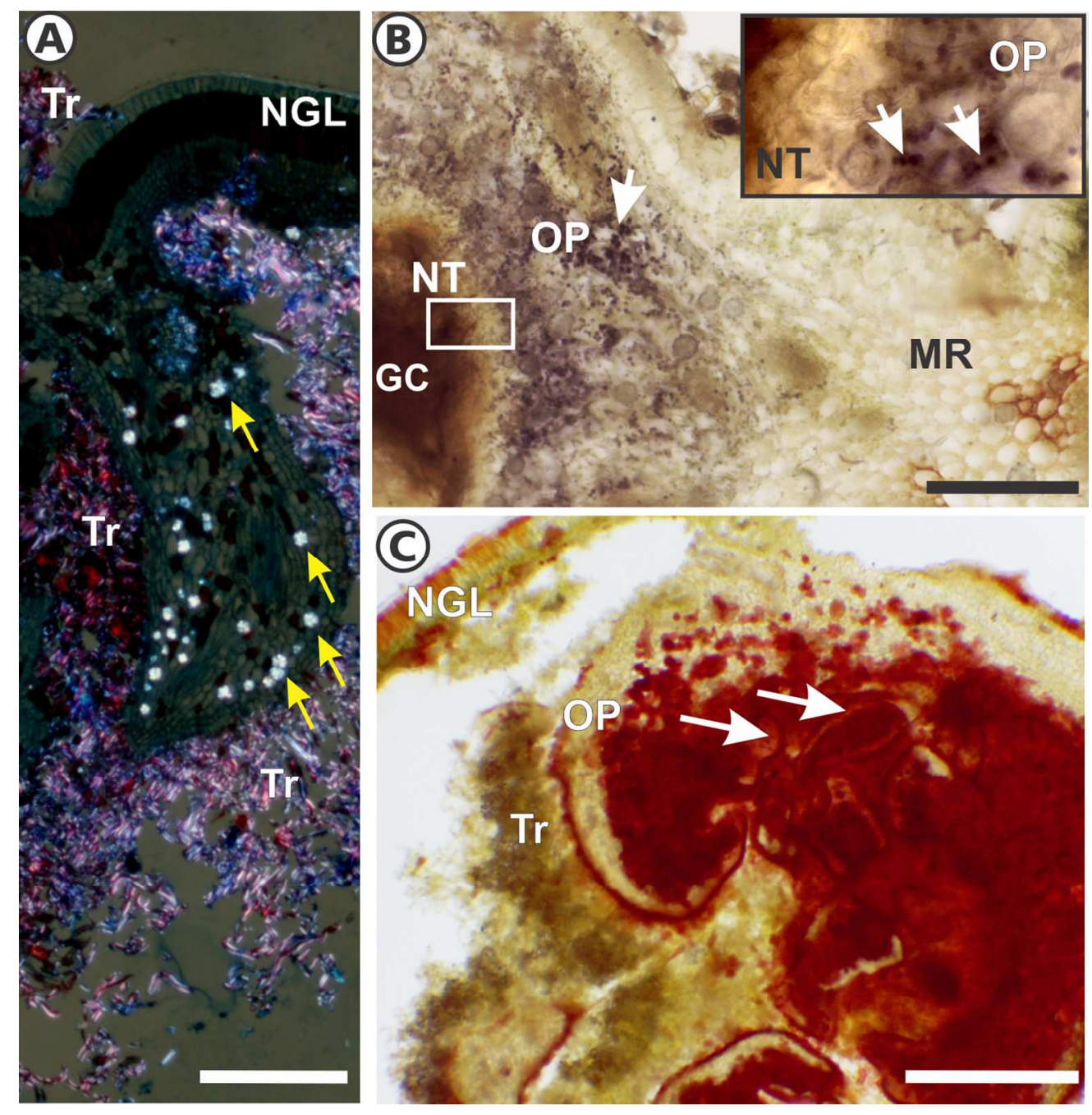

Fig. 4

Fig. 4

$126 \times 129 \mathrm{~mm}(300 \times 300 \mathrm{DPI})$ 


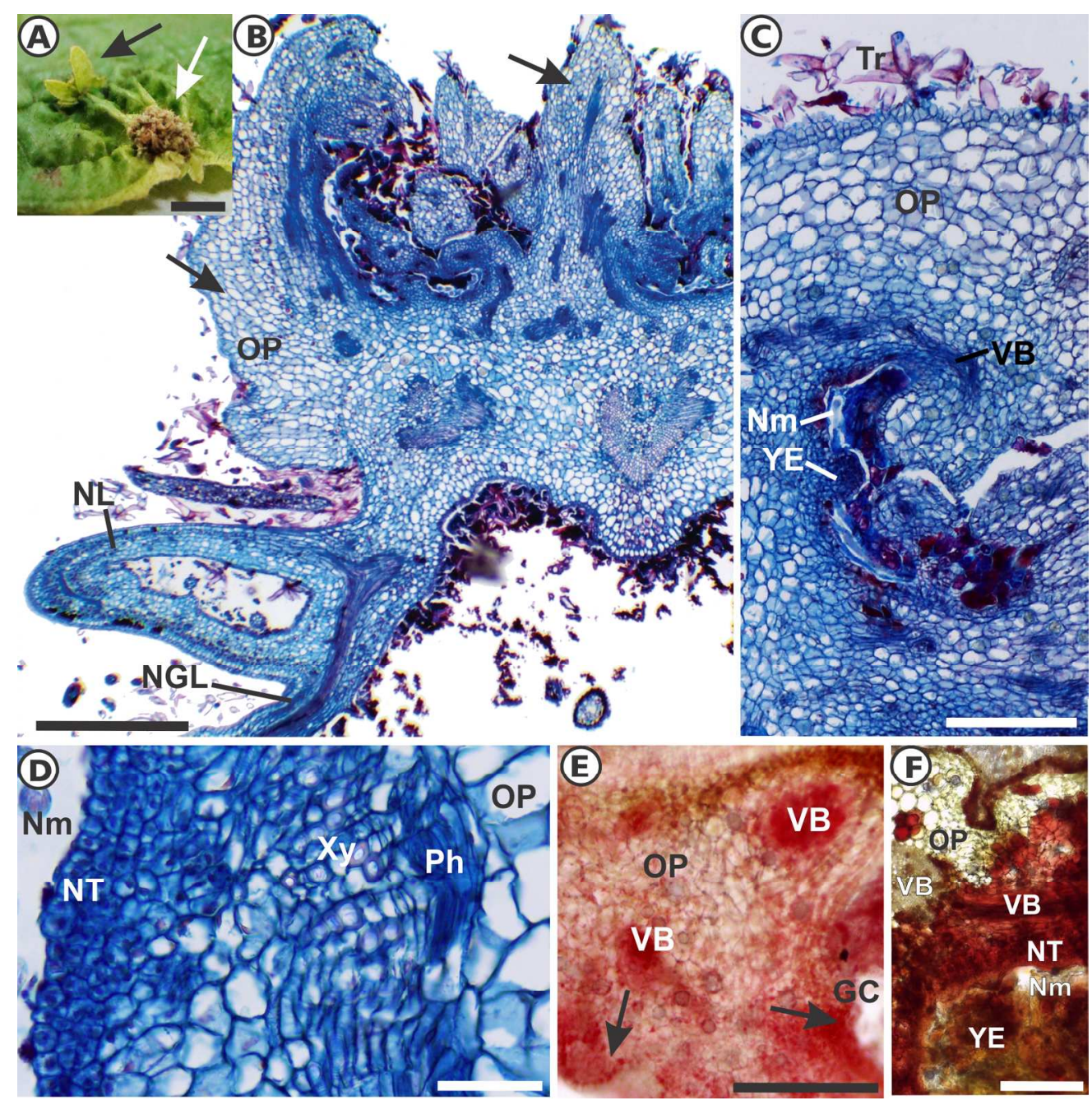

Fig. 5

Fig. 5

$166 \times 168 \mathrm{~mm}(300 \times 300 \mathrm{DPI})$ 


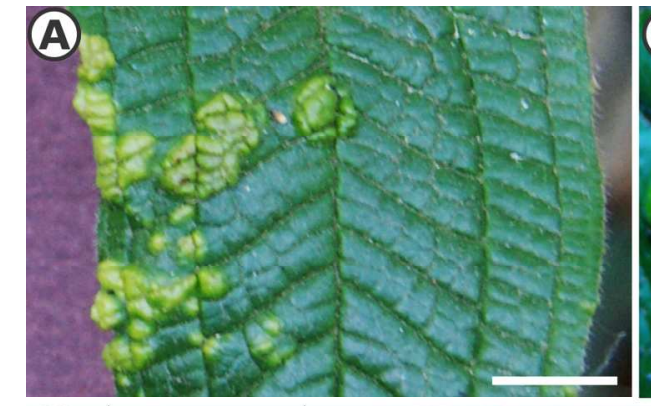

(D) Gall
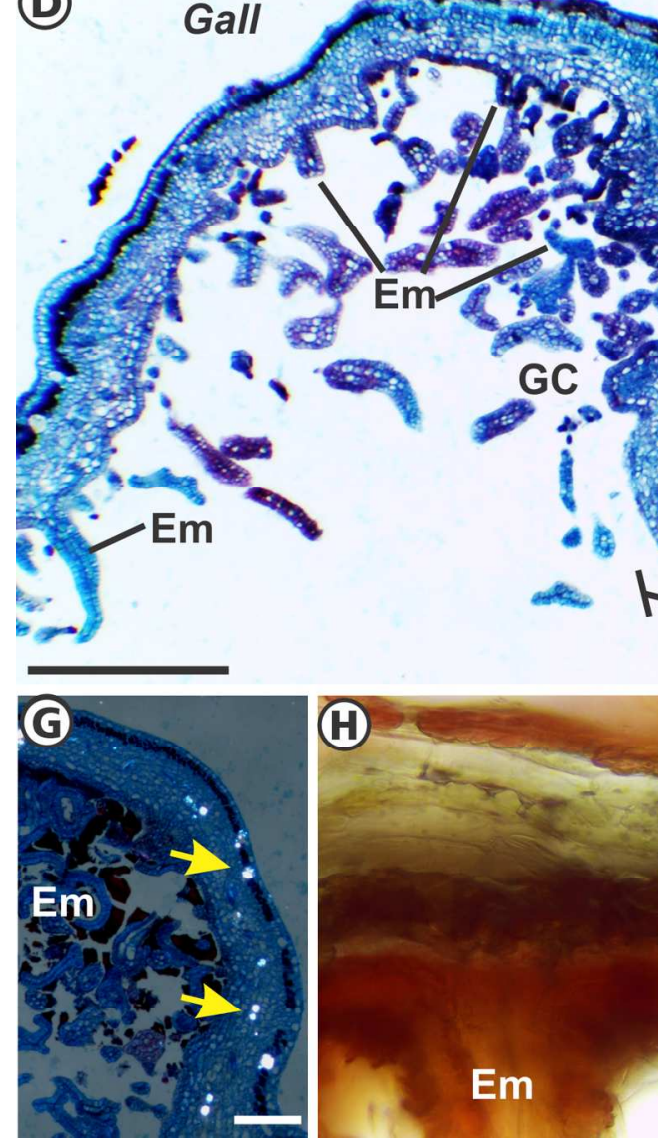

5.
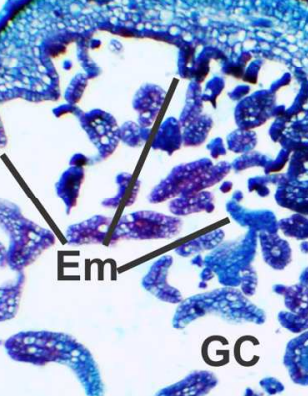
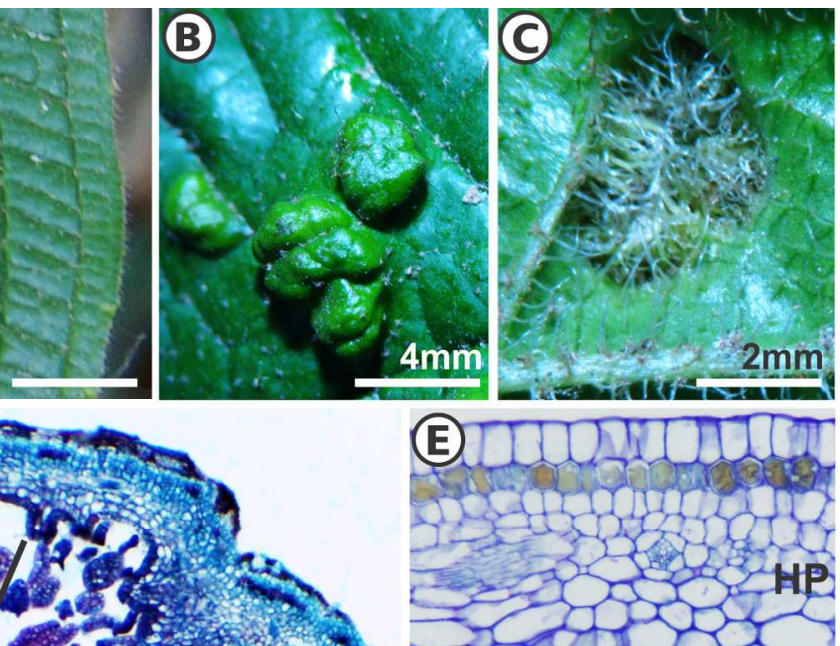

2.. 18
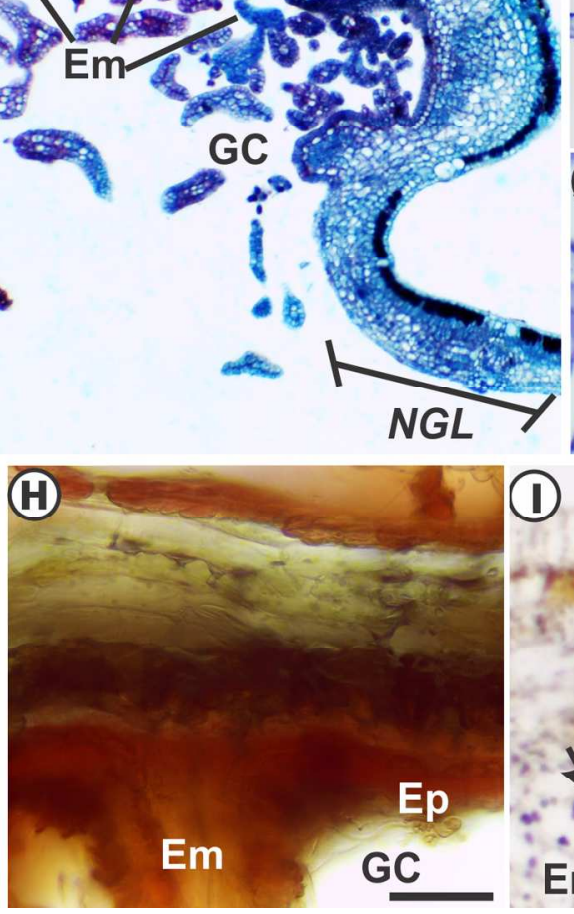

(1)
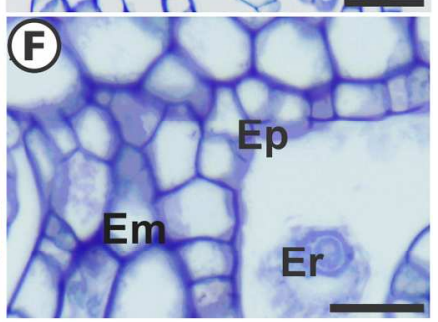

Fig. 6

Fig. 6

$154 \times 187 \mathrm{~mm}(300 \times 300$ DPI $)$ 


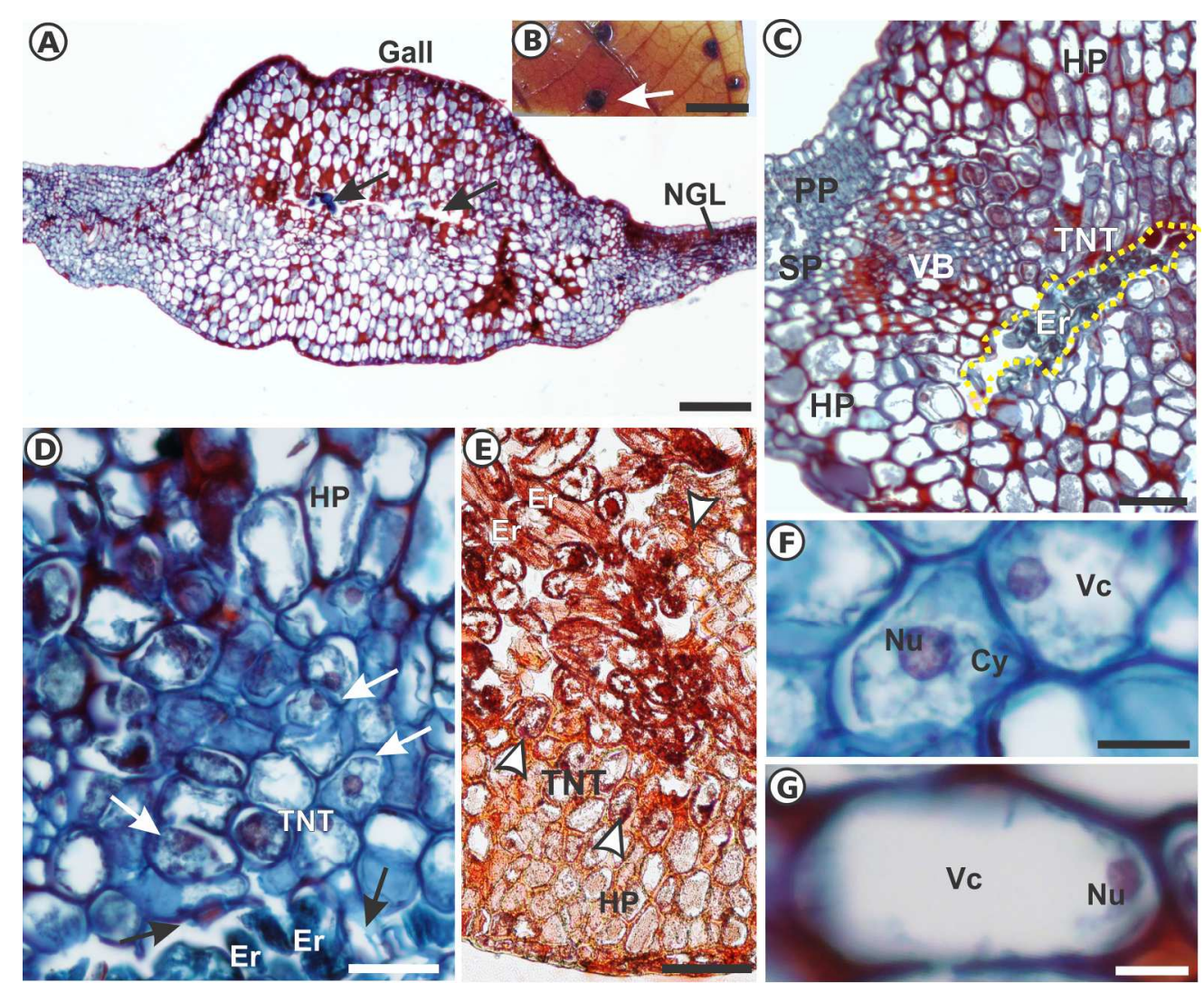

Fig. 7

Fig. 7

$197 \times 161 \mathrm{~mm}(300 \times 300$ DPI $)$ 